\title{
Effect of Pressure on the Caking Propensity of Waterberg Coal
}

\author{
Hardus Louw and John.R. Bunt
}

\begin{abstract}
In this study the high-pressure caking behavior of large Waterberg coal particles $(4,8,10$ and $20 \mathrm{~mm})$ was investigated. This coal was density separated into the following fractions: FL1.3, FL1.5, FL1.7, FL 1.9 and SI 1.9. Small samples (10-20g) of the 4,8,10 and $20 \mathrm{~mm}$ density separated lump coal were reacted in a high-pressure reactor at 4 different pressures (Atm, 7.5, 15, and 30bar) at fixed temperatures of $450^{\circ} \mathrm{C}$ and $550^{\circ} \mathrm{C}$. A $7^{\circ} \mathrm{C}$ per minute heating rate was employed during all experiments, which was executed in an inert nitrogen atmosphere. The degree of caking was determined on a mass\% basis. X-ray computed tomography scans were conducted on the high caking density fraction FL1.3 and parent coal. Conventional coal characterization (proximate and ultimate) and petrographic analysis before and after devolatilization of the $10 \mathrm{~mm}$ density separated coal fraction was also conducted. Finally, a predictive caking model was developed based on the coal properties. The caking propensity was found to be higher under 30bar pressure than at atmospheric conditions $(0.87 \mathrm{bar})$ for the $10 \mathrm{~mm}$ particles, subjected to density cuts (FL1.5 and FL1.7) and the parent coal. The FL1.3, FL1.9 and SI1.9 fractions reported the same caking propensities under both $30 \mathrm{bar}$ and atmospheric pressures. On the other hand, the 4 and $8 \mathrm{~mm}$ particles reported higher caking propensities at $550^{\circ} \mathrm{C}$ than for $450^{\circ} \mathrm{C}$ at 0.87 and $30 \mathrm{bar}$ pressure respectively. The $20 \mathrm{~mm}$ particles reported slightly higher caking propensities $(5 \%)$ than for the $10 \mathrm{~mm}$ particles at $30 \mathrm{bar}$ and $550^{\circ} \mathrm{C}$. It was also found that the caking propensity reaches a maximum at 15 bar pressure for the $10 \mathrm{~mm}$ particles. It is concluded that as the coal fractional density increases the caking propensity decreases. From the $\mathrm{x}$-ray micro focus tomography results it is clear that the porosity of the caked particles decreases and the coalescence of the particles increase as the pressure increases. From characterization analysis it was found that the lighter density cuts contain more volatile matter, a higher $\mathrm{CV}$ value, lower ash content and higher vitrinite maceral composition, leading to higher caking propensity.
\end{abstract}

Index Terms — Fixed bed dry bottom gasification, Syngas, Coal, Devolatilization, Caking propensity, Tomography, CV value

\section{INTRODUCTION}

The Lurgi fixed-bed gasifier is an extremely robust device that can handle coal feedstock having a wide range of properties and operates at approximately 30bar using a coal

Manuscript received November,10, 2017. The work presented in this paper is based on the research financially supported by the South African Research Chairs Initiative of the Department of Science and Technology and National Research Foundation of South Africa. Any opinion, finding or conclusion or recommendation expressed in this material is that of the author(s) and the NRF does not accept any liability in this regard.

H. Louw is with the School of Chemical and Minerals Engineering, NorthWest University, Potchefstroom, South Africa

(e-mail: hlouw.nwu@gmail.com).

J.R. Bunt is with the School of Chemical and Minerals Engineering, NorthWest University, Potchefstroom, South Africa (e-mail: john.bunt@nwu.ac.za). particle size range of 5-100mm [1,2]. The swelling and caking propensities of coal however pose a significant risk to process efficiencies and may lead to operational difficulties such as channeling, excessive pressure build-up and obstruction of gas flow through agglomerates in coal fixed-bed gasification operations [1]. Consequently, these operational difficulties degrade the syngas quality. As a result, the swelling and caking propensities of certain coals make them less suitable for their utilization as a feedstock in fixed-bed gasification processes, and thus a required blend of coal is necessary to minimize the effect of caking within these gasifiers [1,2]. It is thus important to understand the devolatilization of caking coal under high pressure which is crucial for the utilization of coal in new or improved/enhanced technologies. Coal devolatilization, also identified as pyrolysis, is a significantly imperative industrial process, as it is the preliminary step of combustion and gasification [3]. The products of this step include: gas liquor, char, coke, tar and syngas [4]. The chemical and physical behavior of coal under thermal heat treatment is mainly dependent on the operating conditions i.e. temperature, particle size, coal rank and type, and maceral composition respectively $[4,5]$.

Raw Waterberg coal is also comprised of vitrinite macerals with a concentration of up to $90 \%$ weight by volume $[6,7,8]$. The main difficulty with the high ash and vitrinite content is that, this coal tends to swell and cake significantly during devolatilization (thermal treatment), leaving it irreconcilable for fixed-bed gasification purposes, unless the coal is beneficiated or the gasifiers are adjusted according to caking propensities under its operating conditions, i.e. by coal blending, or mechanically stirred to break down cakes $[7,8]$.

Nonetheless, optimization of this fixed-bed gasification process with respect to caking propensities of coal under high pressure, remains a major challenge in progressing the understanding applicable to this technological field. Thus, it is evident that this motivates the study that can contribute to the prediction and understanding of caking coal gasification behavior, especially as a function of pressure and related back to coal properties. In parallel, the gasification operations can also perhaps benefit from this in terms of an improved control philosophy of their process, based on this caking dilemma, yielding better gasification stability, improved efficiency, and ultimately in return, reducing operational expenses in the future.

\section{Methodology}

\section{A. Sample preparation and characterization}

A South African coal from the Grootegeluk area (Waterberg) with a free swelling index of 6 was sampled and 
density separated into floats and sinks fractions as FL1.3, F11.5, FL1.7, FL1.9, SI1.9 and the parent coal. The particles were then sieved using a Fritsch Analysette 3 Spartan vibratory sieve-shaker to obtain approximately 4 - 20mm particle sizes. The density fractions were characterized by means of proximate (ACT-TPM-010, ACT-TPM-011, ACTTPM-012, АCT-TPM-013, АCT-TPM-014, АCТ-TPM-015), ultimate analysis (based on ISO 29541) and petrographic analysis (based on ISO 7404-4) to obtain the conventional and petrographic properties.

\section{B. Devolatilization setup and operating conditions}

Devolatilization experiments were conducted using a Fischer Assay Oven. The Fischer Assay Setup contains a modified stainless-steel reactor. The experimental setup can pressurize the reactor ( $\max 100 \mathrm{bar}$ ), condensing volatile matter and producing char particles for analysis of these devolatilized products. Small samples (10-20g) of the coal particles were placed in a sample holder inside the highpressure reactor housed in the Fischer assay oven as depicted in Fig 1. The oven was closed and it was ensured that the thermocouple and pressure pipelines were securely protruding out from the oven in order to correctly measure the temperature and pressure. The oven was switched on and set to heat up the reactor to $550^{\circ} \mathrm{C}$ with a holding time of $30 \mathrm{~min}$, where after the reactor was cooled to room temperature $\left(25^{\circ} \mathrm{C}\right)$. After the devolatilization took place the sample holder was removed and analysis were conducted.

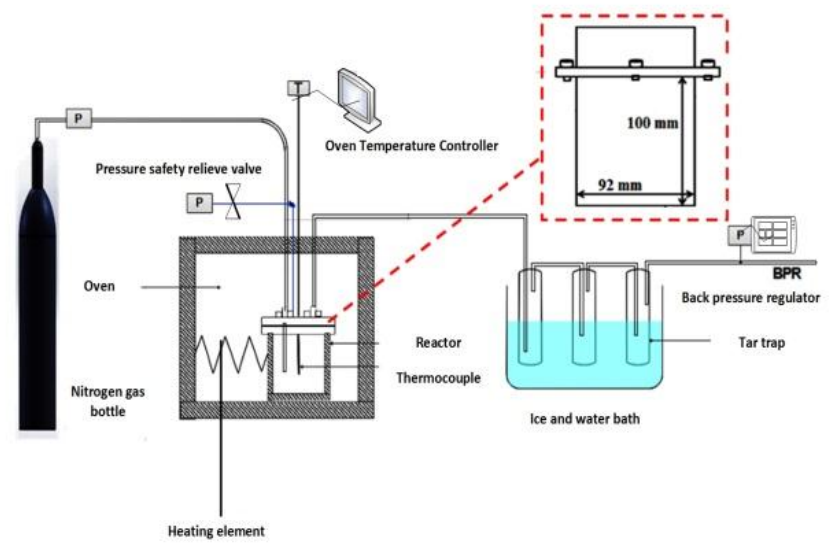

Fig 1: Setup for the devolatilization experiments

The system is equipped with a TOHO TTM-P4 temperature regulator and TOHO $\mathrm{CN}-40$ temperature sensors which are connected to K_type thermocouples which provides readings for the reactor bed and oven temperatures. The temperature of the oven was set to two respective temperatures $\left(450^{\circ} \mathrm{C}\right.$ and $550^{\circ} \mathrm{C}$ ). Pressure inside the reactor was determined with the use of a WIKA UT-10 back pressure regulator. Nitrogen gas was used as an inert agent and in order to pressurise the reactor to $(7.5,15$ and $30 \mathrm{bar})$.

\section{Determination of caking propensity}

The degree of caking was determined by a method that includes weighing the dry devolatilized product and determining the degree of caking on a mass basis as in equation (1)

$$
\text { Caking } \%=\left(\frac{M_{C}}{M_{T}}\right) \times 100
$$

$M_{c}$ is classified as the mass of the caked char determined after devolatilization took place and $M_{T}$ is the total mass of the char formed after devolatilization.

\section{Micro-focus X-ray (CT) tomography scans}

The scans were done using a Nikon XTH 225 ST microfocus tomography system as displayed in Fig 2 [9]. A sample is placed on the sample manipulator and is then horizontally optimized for maximum resolution. This allows for 2D radiographs being included at all angles of rotation. Approximately $10002 \mathrm{D}$ slices are used to reconstruct a 3D view [9].

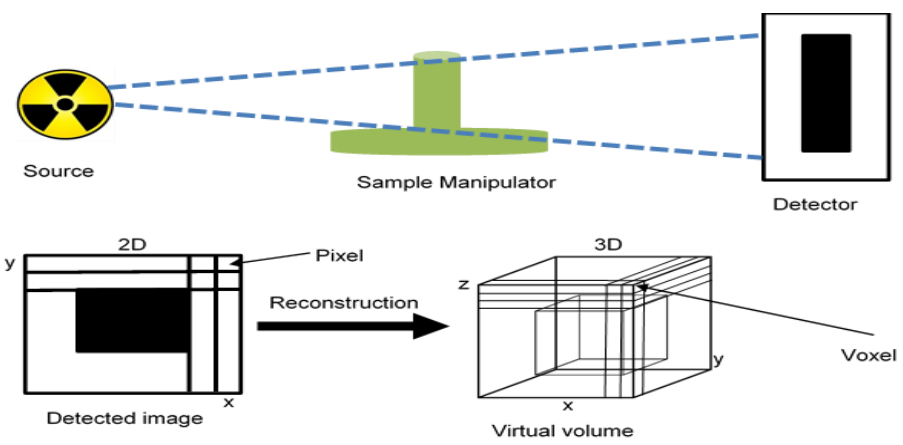

Fig 2 Tomographic process at NECSA [11]

\section{RESULTS AND DISCUSSION}

\section{A. Characterization}

TABLE 1 shows the proximate, ultimate and petrographic analysis results obtained for the different density fractions of the Waterberg coal.

\section{B. Caking experiments}

Fig 3 Illustrates the caking behavior of 4 and $8 \mathrm{~mm}$ particles under temperatures of $450^{\circ} \mathrm{C}$ and $550^{\circ} \mathrm{C}$ and pressures of $0.87 \mathrm{bar}$ and $30 \mathrm{bar}$. It is evident that as the density fractions increases that the caking propensity decreases. The caking propensity of the $8 \mathrm{~mm}$ particles is higher than for the $4 \mathrm{~mm}$ particles. Under $30 \mathrm{bar}$ pressure both the $4 \mathrm{~mm}$ and $8 \mathrm{~mm}$ particles exhibited a higher caking propensity than at atmospheric conditions $(0.87 \mathrm{bar})$. In addition, at $550^{\circ} \mathrm{C}$ the caking propensity tends to be higher than at $450^{\circ} \mathrm{C}$. The caking propensity values for the 4 and $8 \mathrm{~mm}$ particles can be seen in TABLE. The FL1.3 fraction displayed the highest caking propensity for the 3 fractions tested. 
TABLE I PROXIMATE, ULTIMATE AND PETROGRAPHIC ANALYSIS RESULTS

\begin{tabular}{|c|c|c|c|c|c|c|c|}
\hline Analysis & Basis & Parent coal & FL1.3 & FL1.5 & FL1.7 & FL1.9 & SI1.9 \\
\hline \multicolumn{8}{|l|}{ Proximate analysis } \\
\hline wt.\% Inherent moisture content & ad & 1.7 & 2.1 & 1.9 & 2.1 & 1.6 & 1.8 \\
\hline wt.\% Ash yield & ad & 35.1 & 8.8 & 20.6 & 26.9 & 45.4 & 57.9 \\
\hline wt.\% Volatile Matter & ad & 23.2 & 34.1 & 28.7 & 26.4 & 21.0 & 20.0 \\
\hline wt.\% Fixed carbon & ad & 40.0 & 55 & 48.8 & 44.6 & 32 & 20.3 \\
\hline Gross Calorific value (MJ/kg) & ad & 19.3 & 30 & 25.1 & 22.8 & 15.6 & 8.9 \\
\hline \multicolumn{8}{|l|}{ Ultimate analyses (air dried) } \\
\hline wt.\% Carbon Content & ad & 77.5 & 81.5 & 79.2 & 79.0 & 76.1 & 57.3 \\
\hline wt. \% Hydrogen Content & ad & 5.0 & 5.2 & 4.9 & 5.1 & 5.4 & 4.7 \\
\hline wt. \% Nitrogen Content & ad & 1.6 & 1.8 & 1.7 & 1.7 & 1.7 & 1.4 \\
\hline wt.\% Oxygen Content & ad & 13.4 & 10.4 & 12.6 & 13.0 & 15.9 & 0.3 \\
\hline wt.\% Total Sulphur & ad & 2.4 & 1.0 & 1.5 & 1.2 & 0.9 & 36.4 \\
\hline \multicolumn{8}{|l|}{ Petrographic analyses m.m.f.b } \\
\hline Vitrinite & m.m.f.b & 21.3 & 60.5 & 28.8 & 34.4 & 9.2 & 50.0 \\
\hline Liptinite & m.m.f.b & 9.5 & 4.9 & 6.0 & 8.5 & 8.0 & 1.0 \\
\hline Inertinite & m.m.f.b & 69.2 & 34.6 & 65.3 & 57 & 82.8 & 49.0 \\
\hline
\end{tabular}

TABle I Degree Of Caking For 4 And 8Mm Particle Sizes At Temperatures Of $450^{\circ} \mathrm{C}$ And $550^{\circ} \mathrm{C}$ And Pressure OF 0.87 AND 30BAR

\begin{tabular}{|c|c|c|c|c|c|c|c|c|}
\hline \multirow{2}{*}{$\begin{array}{l}\begin{array}{l}\text { Particle } \\
\text { size }\end{array} \\
\text { Density }\end{array}$} & \multicolumn{4}{|c|}{$4 \mathrm{~mm}$} & \multicolumn{4}{|c|}{$8 \mathrm{~mm}$} \\
\hline & $\operatorname{ATM}\left(550^{\circ} \mathrm{C}\right)$ & $30 \mathrm{bar}\left(550^{\circ} \mathrm{C}\right)$ & $\operatorname{ATM}\left(450^{\circ} \mathrm{C}\right)$ & $30 \operatorname{bar}\left(450^{\circ} \mathrm{C}\right)$ & $\begin{array}{l}\text { ATM } \\
\left(550^{\circ}\right)\end{array}$ & $30 \operatorname{bar}\left(550^{\circ} \mathrm{C}\right)$ & $\operatorname{ATM}\left(450^{\circ} \mathrm{C}\right)$ & $30 \mathrm{bar}\left(450^{\circ}\right)$ \\
\hline FL1.3 & $\begin{array}{l}65 \% \pm \\
13.5 \%\end{array}$ & $87 \% \pm 13 \%$ & $58 \% \pm 6 \%$ & $61 \% \pm 4.9 \%$ & $100 \% \pm 0 \%$ & $100 \% \pm 0.7 \%$ & $74 \% \pm 1.9 \%$ & $74 \% \pm 1.6 \%$ \\
\hline Feed & $23 \% \pm 1 \%$ & $30 \% \pm 1.3 \%$ & $16 \% \pm 2.8 \%$ & $18 \% \pm 4.4 \%$ & $\begin{array}{c}50 \% \pm \\
2.8 \%\end{array}$ & $65 \% \pm 12.3 \%$ & $10 \% \pm 3.2 \%$ & $29 \% \pm 6.7 \%$ \\
\hline SI 1.9 & $0 \pm 0 \%$ & $0 \pm 0 \%$ & $0 \pm 0 \%$ & $0 \pm 0 \%$ & $0 \pm 0 \%$ & $0 \pm 0 \%$ & $0 \pm 0 \%$ & $0 \pm 0 \%$ \\
\hline
\end{tabular}

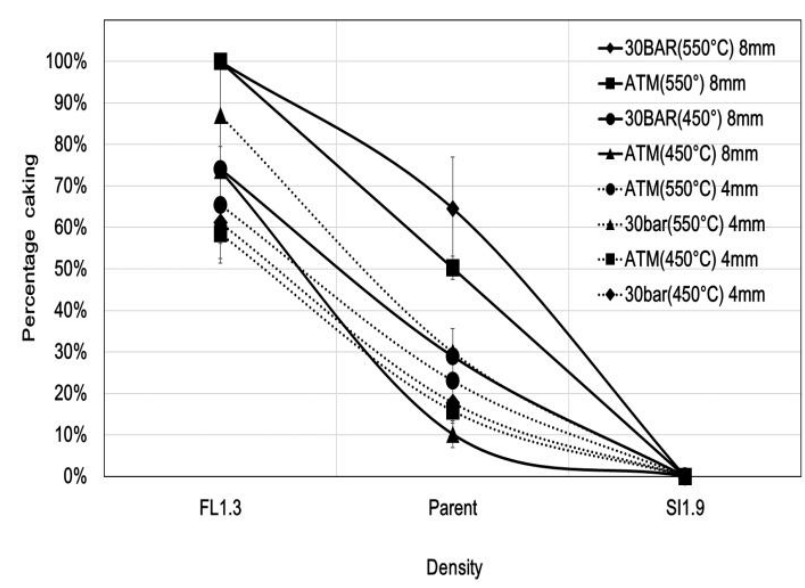

Fig 3 Caking experiments results for 4 and $8 \mathrm{~mm}$ particles at temperatures of $450^{\circ} \mathrm{C}$ and $550^{\circ} \mathrm{C}$ and pressures of $\operatorname{ATM}(0.87 \mathrm{bar})$ and $30 \mathrm{bar}$.

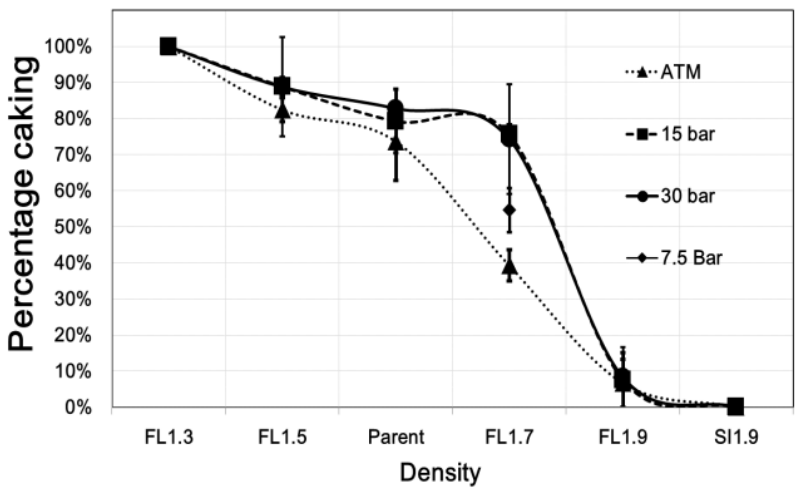

Fig 4 Caking experiments results for $10 \mathrm{nmm}$ particles at a temperature of $550^{\circ} \mathrm{C}$ and pressures of $\operatorname{ATM}(0.87 \mathrm{bar}), 7.5,15$ and $30 \mathrm{bar}$

Fig 4 shows the caking propensity behavior for the $10 \mathrm{~mm}$ particles at a fixed temperature of $550^{\circ} \mathrm{C}$ and pressure of 0.87 , $7.5,15$ and 30bar. It is evident that the caking propensity decreases as the respective fractional density increases. The highest caking propensity was observed at the lowest density fraction FL1.3. There exists a clear trend between the density fractions and the percentage caking. The FL1.3, FL1.9 and SI1.9 fractions reported the same caking propensities under atmospheric pressure, 15 and 30bar. On the other hand, the FL1.5 and FL1.7 yielded similar caking propensities under 15 
and 30bar respectively. The parent coal however exhibited different caking propensities under atmospheric, 15 and 30bar pressures. It is also observed that caking reaches a maximum at a pressure of 15 bar for the density fractions as can be seen in TABLE II.

TABLE II CAKING RESULTS FOR 10MM PARTICLE SIZE AT A TEMPERATURE OF $550^{\circ} \mathrm{C}$ AND PRESSURES OF 0.87, 7.5, 15 AND

\begin{tabular}{lllll}
\multicolumn{5}{c}{$30 \mathrm{bar}$} \\
\hline Density cut & \multicolumn{1}{c}{ Atm } & \multicolumn{1}{c}{$15 \mathrm{bar}$} & \multicolumn{1}{c}{$30 \mathrm{bar}$} & $7.5 \mathrm{bar}$ \\
\hline \hline FL1.3 & $100 \% \pm 0 \%$ & $100 \% \pm 0 \%$ & $100 \% \pm 0 \%$ & \\
FL1.5 & $82 \% \pm 3.4 \%$ & $89 \% \pm 2.5 \%$ & $89 \% \pm 13.7 \%$ & \\
FEED & $74 \% \pm 12.5 \%$ & $79 \% \pm 8.8 \%$ & $83 \% \pm 0.9 \%$ & \\
FL1.7 & $39 \% \pm 4.3 \%$ & $76 \% \pm 2.7 \%$ & $74 \% \pm 15.2 \%$ & $55 \% \pm 6.0 \%$ \\
FL1.9 & $7 \% \pm 6.6 \%$ & $8 \% \pm 7.5 \%$ & $8 \% \pm 8.3 \%$ & \\
SI1.9 & $0 \% \pm 0 \%$ & $0 \% \pm 0 \%$ & $0 \% \pm 0 \%$ & \\
\hline
\end{tabular}

Indicated in Fig 5 and Table III are the caking propensity results for the 10 and $20 \mathrm{~mm}$ particles at $550^{\circ} \mathrm{C}$ and $30 \mathrm{bar}$ respectively. The caking propensity is not significantly higher at particle sizes of $20 \mathrm{~mm}$ compared to $10 \mathrm{~mm}$; a slight increase of an average of $4 \%$ is observed from the density fractions FL1.5 and FL1.7 respectively. Visual images of the caking propensities can be seen in Tables V-VIII.

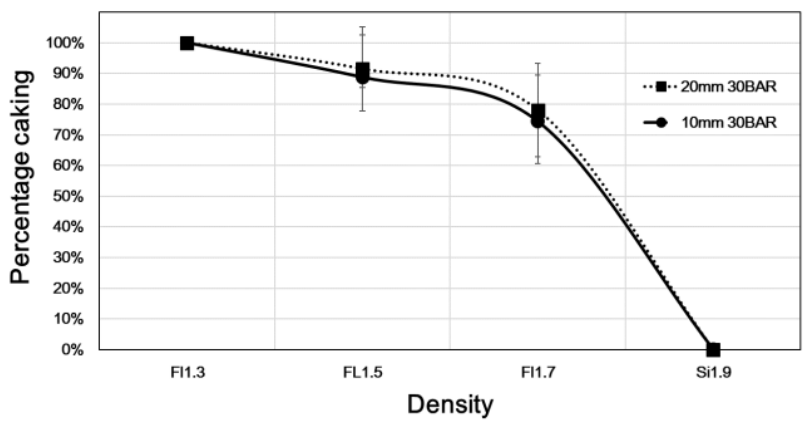

Fig 5 Caking experiment results for 10 and $20 \mathrm{~mm}$ particles at a temperature of $550^{\circ} \mathrm{C}$ and pressure of 30 bar.

TABle III CAKING RESUlts For 10 AND 20MM PARTICles At $550 \uparrow \mathrm{C}$ AND

\begin{tabular}{ccc}
\multicolumn{3}{c}{ 30BAR } \\
\hline Density & $10 \mathrm{~mm}$ & $20 \mathrm{~mm}$ \\
\hline \hline FL1.3 & $100 \% \pm 0 \%$ & $100 \% \pm 0 \%$ \\
FL1.5 & $89 \% \pm 13.7 \%$ & $92 \% \pm 15.1 \%$ \\
FL1.7 & $74 \% \pm 15.2 \%$ & $78 \% \pm 3.2 \%$ \\
SI1.9 & $0 \% \pm 0 \%$ & $0 \% \pm 0 \%$ \\
\hline
\end{tabular}

TABle IV Photographs SHOWING 4Mm Fl1.3 CAKed Particles AT $550^{\circ} \mathrm{C}$, ATM AND 30BAR PRESSURE

\begin{tabular}{|c|c|c|}
\hline $\begin{array}{c}550^{\circ} \mathrm{C} \\
\mathrm{FL} 1.3(\mathrm{~mm})\end{array}$ & Before & After \\
\hline \hline $\mathrm{Atm}$ & & \\
& & \\
\hline \hline $30 \mathrm{Bar}$ & & \\
& & \\
& & \\
\hline
\end{tabular}

Table V Photographs Showing 8Mm Fl1.3 CAKed ParTicles At $550^{\circ} \mathrm{C}$, ATM AND 30BAR PRESSURE

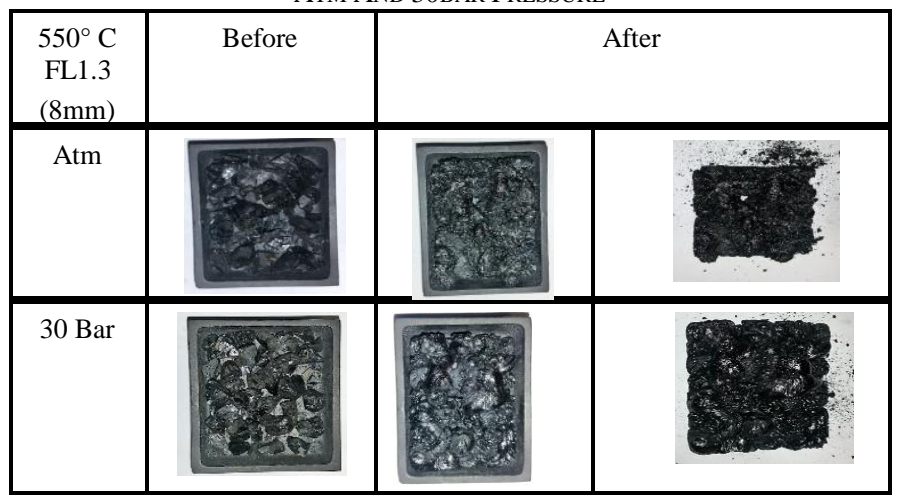

TABle VI PhotographS SHOWING 10Mm Fl1.3 CAKed PaRTiCLES AT $550^{\circ} \mathrm{C}$, ATM AND ATM, 15 AND 30 BAR PRESSURES

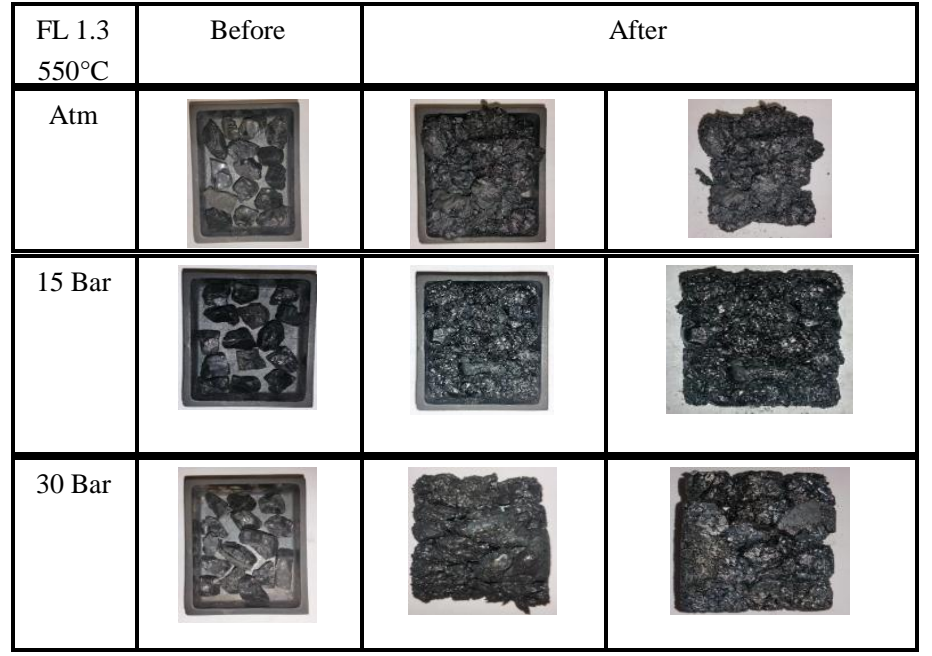

TABLE VII PHOTOGRAPHS SHOWING 20MM FL1.3 AND Si 1.9 CAKED Particles AT $550^{\circ} \mathrm{C}$, ATM AND 30BAR PRESSURE

\begin{tabular}{|c|c|c|c|}
\hline $\begin{array}{c}550^{\circ} \mathrm{C}(20 \mathrm{~mm}) \\
\text { 30BAR }\end{array}$ & Before & \multicolumn{2}{|c|}{ After } \\
\hline \hline FL1.3 & rest & \\
& & & \\
\hline \hline FL1.5 & & & \\
& & & \\
\hline
\end{tabular}

C. Micro focus $x$-ray tomography $(C T)$ scans

Micro-focus X-ray (CT) slices of the caked $10 \mathrm{~mm}$ particles at $550^{\circ} \mathrm{C}$ and three pressure levels (ATM, 15 and 30bar), were taken approximately in the half of the caked lump to examine the effect that pressure has on the caking propensity and physical characteristics of the caked particles. Table VIII and Table IX indicate these slices taken for the FL1.3 fraction and parent coal respectively. For the FL1.3 fraction the pores and bubble rupture are significantly larger at atmospheric pressure than at 15 or $30 \mathrm{bar}$. It is also clear that the particles also form a better unity under higher pressures (15 and 30bar). Thus, the 
porosity appears to decrease and the coalescence increases as the pressure increases. Similarly, for the parent coal it is observed that the particles also form a better unity under higher pressure (15 and 30bar). The parent coal exhibits vast heterogeneity amongst the particles as it is clear that different density fractions constitute the parent coal. The mineral matter is generally presented by the white matter, the grey matter is the resultant coke/char, and the black matter in-between the

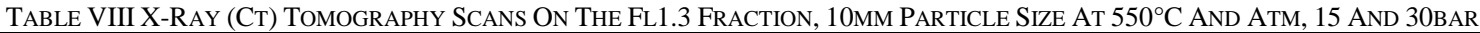

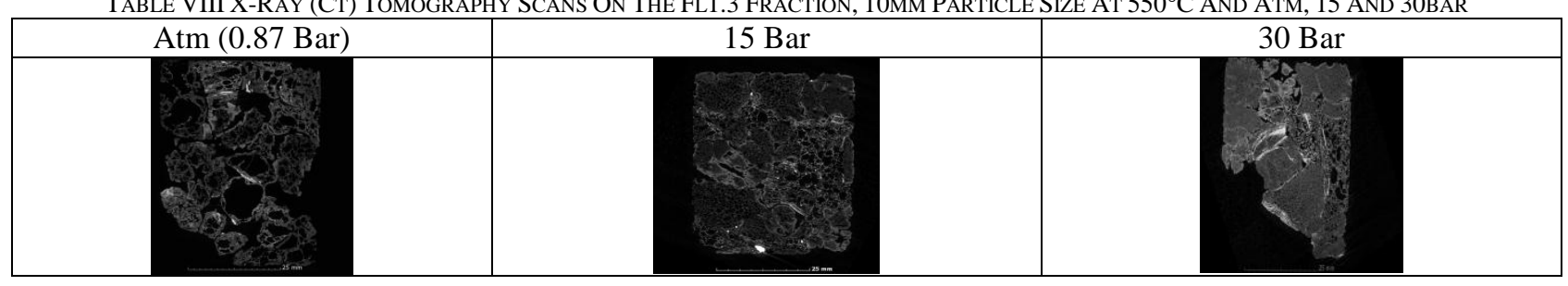

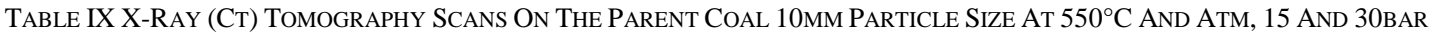

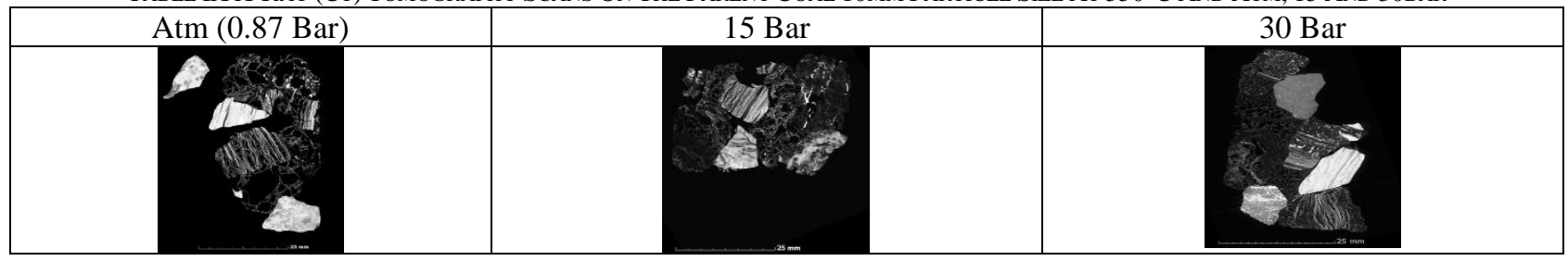

\section{Statistical model}

An empirical equation was derived to predict the caking propensity of this coal under high pressure i.e. 30bar. Certain coal properties that displayed the high inter correlation factors with regards to the degree of caking were incorporated into this model. The coal properties that intercorrelated too strongly with one another (ro >0.6) were not used together in the model as they carry the same statistical weight towards the model [10]. Thus, the correlation factors for the coal properties used in this model towards caking can be seen in

Table XI.

Table XI SPEARMAN'S RHO INTER-CORRELATION FACTOR

\begin{tabular}{|l|l|}
\hline Coal property & $\mathrm{r}_{\mathrm{O}}$ \\
\hline Volatile matter / inherent moisture & 0.87 \\
\hline Maceral index [12] & 0.78 \\
\hline Carbon content & 0.86 \\
\hline
\end{tabular}

The empirical equation derived from these parameters when using the SPSS software is displayed in equation (2) with an R2 value of $87 \%$, which indicates good variance of the data amongst the model $[10,11]$.

$$
P_{\% \text { CAKING }}=0.046 \frac{V M}{I M}+0.267 M I-0.017 C+0.412
$$

Illustrated in Fig 6 is the normal distribution of this model in the form of a Quantile-quantile plot for the unstandardized residuals. particles are the pores. It can also be observed form the tomography scans that more mineral matter is present in the parent coal than is the case for the FL1.3 fraction. The difference in caking behavior under ATM, 15 and 30bar can also possibly be attributed to this phenomenon of coal heterogeneity. 
observed to be higher than at atmospheric conditions. A possible explanation for this is that more volatile matter and moisture content is driven off at higher pressures. From characterization data it was found that the lighter density fractions have a high content of volatile matter, vitrinite, a high $\mathrm{CV}$ value and low ash content. Thus, the caking propensity increases as the fractional density decreases. Thus, the higher the volatile matter, CV value, vitrinite content and the lower the ash content the higher the caking propensity will be. From the Micro-focus x-ray tomography images, it is evident that at higher pressures that the caked particles tend to exhibit a lower porosity and higher coalescence. It is also evident that under atmospheric conditions that the bubble rupture and pore structure is much larger than under 30bar pressure. The predictive caking model developed under 30bar pressure included 3 parameters, the maceral index [12], volatile matter divided by inherent moisture (pore resistance number), and the carbon content. This model has an $\mathrm{R}^{2}$ value of $87 \%$, which is an acceptable model considering that $87 \%$ of the experimental data is incorporated into the model.

\section{ACKNOWLEDGMENT}

H. Louw and John.R. Bunt would like to thank NECSA for assisting with the micro-focus $\mathrm{X}$-ray tomography scans and the statistical department at North West University in the assistance with statistical analysis.

\section{REFERENCES}

[1] J. Van Dyk, S. Benson, M. Lomb and F. Waanders, "Coal and coal ash characteristics to understand mineral transformations and slag formation.," Fuel, vol. 88, pp. 1057-1063, 2009.

[2] M. Keyser, M. COnradie and J. van Dyk, "Effect of coal particle size distribution on packed bed pressure and gas flow distribution," Fuel, vol. 85, pp. 1439-1445, 2006.

[3] A. Arenillas, C. Pevida, F. Rubiera, R. Garcia and J. Pis, "Characterisation of model compounds and a synthetic coal by TG/MS/FTIR to represent the pyrolysis behaviour of coal," Journal of Analytical Applied Pyrolysis, vol. 71, pp. 747-767, 2004.

[4] M. Alonso, A. Borrego, D. Alvarez and R. Menendez, "Pyrolysis behaviour of pulverised coals at different temperatures," Fuel, vol. 78, pp. 1501-1513, 1999.

[5] E. Hambly, "The Chemical Structure of Coal Tar and Char During Devoltilisation, A thesis Presented to the Department of Chemical Enginering:Brigham Young university," 1998.

[6] Q. Campbell, J. Bunt and F. de Waal, "Investigatoin of lump coal agglomeration in a non-pressurized reactor," Journal of Analytical and Applied Pyrolysis, vol. 89, pp. 271-277, 2010.

[7] N. Wagner and M. Tloleng, "Distribution of selected trace elements in density fractionated Waterberg coals from South Africa," International Journal of Coal Geology, vol. 94, pp. 225-237, 2012.

[8] D. Van Niekerk, R. Pugmire, M. Solum, P. Painter and P. Matews, "Structural characterization of vitrinite-rich Permian-aged South African Bituminous coals," International Journal of Coal Geology, vol. 76, pp. 290-300, 2008.

[9] J. Hoffman and F. De Beer, "Characteristics of the Micro-Focus X-ray Tomography Facility (MIXRAD) at Necsa in South Africa,18th World Conference on Nondestructive Testing," Durban, South Africa, 2012.

[10] J. F. Hair, W. C. Black, B. J. Babin, R. E. Anderson and R. L. Tatham, Multivariate Data Analysis, 6th ed., Pearson prentice hall, 2006.

[11] A. Field, Discovering Statistics Using SPSS, 2nd ed., London: Sage Publicatino Ltd, 2005.

[12] S. Helle, A. Gordon, G. Alfaro, X. Garcia and C. Ulloa, "Coal blend combustion: Link between unberunt carbon in fly ash and maceral composition," Fuel Processing Technology, vol. 80, no. 3, pp. 209223, 2003.

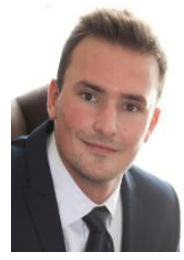

Hardus Louw was born on 3 February 1995 in Otjiwarongo, Namibia, matriculated in 2013 at High School Ferdinand Postma in Potchefstroom. Hardus is set out to complete his B.Eng. degree in chemical engineering in 2017 at the North West University (NWU) Potchefstroom campus He obtained a bursary from Eskom in 2014 and is set to work for Eskom starting 2018 after the completion of his studies. He currently has an interest in renewable energy research and improving coal utilization methods. 